\title{
CORPORATE SOCIAL RESPONSIBILITY SEBAGAI VARIABEL PEMEDIASI PENGARUH GOOD CORPORATE GOVERNANCE TERHADAP KINERJA KEUANGAN
}

\author{
Siti Djamilah \\ Fakultas Ekonomi Universitas Wijaya Kusuma Surabaya \\ djamilahsiti@gmail.com \\ Surenggono \\ Fakultas Ekonomi Universitas Wijaya Kusuma Surabaya \\ natanaelsurenggono@gmail.com
}

Received: $30-09-2017$

Revised: $20-10-2017$

Accepted: $30-10-2017$

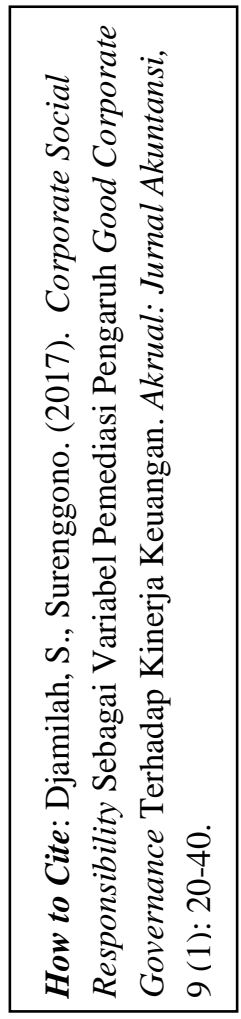

I ABSTRACT

The purpose of this study is to examine the indirect effect of good corporate governance on financial performance through corporate social responsibility. The sampling technique uses purposive sampling based on the criteria: the bank is listed on the Indonesia Stock Exchange (IDX), publishes the annual report and financial report for the period 2010-2014 and didn't any losses. The independent variables are good corporate governance in the form of public ownership, institutional ownership and board size. The mediating variable is corporate social responsibility. The dependent variable is the financial performance in the form of return on asset and return on equity. Analytical technique used structural equation modeling. Of the 31 banks listed on the IDX 2010-2014, there are 29 banks eligible for sampling. The results showed that good corporate governance has a positive and significant impact on corporate social responsibility and corporate social responsibility has a positive and significant impact on financial performance.

Keywords: Banking, Corporate Social Responsibility, Financial Performance, Good Corporate Governance

\section{ABSTRAK}

Tujuan penelitian ini adalah untuk menguji pengaruh tidak langsung good corporate governance terhadap kinerja keuangan melalui corporate social responsibility. Teknik sampling menggunakan purposive sampling berdasarkan pada kriteria: bank terdaftar di Bursa Efek Indonesia (BEI), menerbitkan laporan tahunan dan laporan keuangan periode 2010-2014 dan tidak mengalami kerugian. Variabel bebas penelitian ini adalah good corporate governance yang berupa kepemilikan publik, kepemilikan institusional dan ukuran dewan komisaris. Variabel pemediasi adalah corporate social responsibility. Variabel terikat adalah kinerja keuangan yang berupa return on equity dan return on asset. Teknik analisis yang digunakan adalah structural equation modelling. Dari 31 bank yang terdaftar di BEI tahun 2010-2014, ada 29 bank yang memenuhi syarat untuk dijadikan sampel. Dengan demikian jumlah amatan sebanyak 145 amatan. Hasil penelitian menunjukkan bahwa good corporate governance berpengaruh positif dan signifikan pada corporate social responsibility dan corporate social responsibility berpengaruh positif dan signifikan terhadap return on equity dan return on asset.

Kata Kunci: Corporate Social Responsibility, Good Corporate Governance, Kinerja Keuangan, Perbankan

\section{PENDAHULUAN}

Peraturan Bank Indonesia nomor 13/1/PBI/2011

tentang sistem penilaian kesehatan bank umum, menyebutkan bahwa: Tingkat Kesehatan Bank adalah hasil penilaian kondisi Bank yang dilakukan terhadap risiko dan kinerja Bank. Untuk mengetahui besarnya pertumbuhan kinerja keuangan pada beberapa bank dapat 
Djamilah, Surenggono, Corporate Social Responsibility Sebagai Variabel Pemediasi...

dilihat dari Return on Asset (ROA) yang mewakili pengukuran untuk aspek laba perusahaan atau rentabilitas. ROA berfungsi mengukur efektivitas perusahaan dalam menghasilkan laba dengan memanfaatkan aktiva yang dimiliki (Wardiah, 2013). Semakin tinggi rasio ROA, semakin efisien penggunaan aktiva, sehingga kenaikan laba bersih bank tersebut semakin tinggi. Sebaliknya, rasio ROA yang rendah menggambarkan bank tidak mampu mengelola asetnya untuk menghasilkan laba, sehingga tidak dapat menarik investor karena tingkat kembalian yang rendah. Laba yang rendah tersebut berakibat pada pertumbuhan modal bank, padahal kecukupan modal bank berpengaruh pada kemampuan bank tersebut untuk mengatasi risiko-risiko. Jika ROA suatu bank rendah, maka kualitas tata kelola perusahaan yang dijalankan bank-bank tersebut juga dipertanyakan. Bank Indonesia telah menetapkan batas minimum ROA yaitu sebesar $1 \%$ dalam Surat Ketetapan BI No. 23/67/KEP/DIR/1991.

Kinerja keuangan perusahaan yang lain adalah Return on Equity (ROE). ROE adalah ukuran profitabilitas perusahaan yang mengukur pengembalian untuk pemegang saham (Fachrudin, 2011). Semakin besar ROE yang dihasilkan, mencerminkan kemampuan perusahaan dalam menghasilkan keuntungan yang besar bagi pemegang saham. Perusahaan yang menunjukkan laba atas ekuitas/ modal yang tinggi cenderung lebih mampu menghasilkan laba secara internal (Amri, 2011). ROE merupakan salah satu variabel yang terpenting yang dilihat investor sebelum mereka berinvestasi dan menunjukkan seberapa efektif manajemen perusahaan menggunakan uang investor.

Peningkatan kinerja perusahaan dapat dilakukan melalui pemantauan kinerja manajemen dan adanya akuntabilitas manajemen terhadap pemangku kepentingan lainnya, berdasarkan kerangka aturan dan peraturan yang berlaku atau dengan kata lain melalui Good Corporate Governance (Kaihatu, 2006). Good Corporate Governance (GCG) merupakan seperangkat peraturan yang mengatur hubungan antara pemegang saham, manajer, kreditur, pemerintah, karyawan, dan stakeholders lainnya supaya hak dan kewajiban mereka seimbang. Perusahaan harus memperhatikan hal tersebut karena dalam operasionalnya perusahaan tidak hidup sendiri, melainkan bersama lingkungan sekitar, sehingga perusahaan dan masyarakat tidak ada yang dirugikan.

Survei yang dilakukan oleh McKinsey dan Company dan Political and Economic Risk Consultancy (PERC) tahun 2000 menunjukkan Indonesia menduduki posisi paling terakhir dalam pelaksanaan Good Corporate Governance (Novrianti et al., 2012). Hal ini menunjukkan posisi yang sangat tidak menguntungkan bagi Indonesia. Pasalnya menurut PERC, buruknya corporate governance mengancam kelangsungan masuknya investor ke Indonesia (Sutedi, 2011). Oleh karena itu diperlukan evaluasi terhadap penerapan GCG (Agustina, et al. 2015).

Undang-Undang Perseroan Terbatas Nomor 40 tahun 2007, pasal 66 dan 74. Pasal 66 
AKRUAL: Jurnal Akuntansi, volume 9, nomor 1, Oktober 2017, (41-53)

ayat (2) bagian c berisi kewajiban perusahaan selain menyampaikan laporan keuangan, juga wajib melaporkan pelaksanaan tanggung jawab sosial dan lingkungan. Sedangkan Pasal 74 berisi kewajiban melaksanakan tanggung jawab sosial dan lingkungan bagi perusahaan yang kegiatan usahanya berkaitan dengan sumber daya alam. Tujuan Undang-Undang tersebut, selain untuk mendorong praktik dan pengungkapan Corporate Social Responsibility (CSR), juga untuk memenuhi penerapan $G C G$ rangka pengelolaan perusahaan yang baik.

Corporate Social Responsibility (CSR) merupakan suatu konsep akuntansi yang menekankan tanggung jawab perusahaan terhadap lingkungan dan masyarakat. Praktik dan pengungkapan CSR jika dilakukan secara berkesinambungan oleh perusahaan akan memberikan banyak manfaat bagi perusahaan itu sendiri. Keterlibatan perusahaan atas tanggung jawab sosialnya dapat meningkatkan akses modal, memperbaiki kinerja keuangan, mengurangi biaya operasi, meningkatkan citra dan reputasi, meningkatkan penjualan dan loyalitas pelanggan, meningkatkan produktivitas dan kualitas (Said, et al., 2009).

Peneliti tertarik meneliti pengaruh GCG secara tidak langsung terhadap kinerja keuangan perbankan melalui CSR dengan fokus pada perbankan karena perbankan merupakan peserta yang sering mengikuti riset atau pemeringkatan penerapan GCG menurut The Indonesian Institute for Corporate Governance (IICG) tahun 2005 - 2010. Selain itu sebagai variasi dari 43 penelitian sebelumnya, sektor perbankan wajib melaporkan CSR menurut Pasal 74 ayat $1 \mathrm{UU}$ No. 40 Tahun 2007 tentang Perseroan Terbatas dan Pasal 3 PP No. 47 Tahun 2012 tentang Tanggung jawab Sosial dan Lingkungan Perseroan Terbatas.

Tujuan penelitian ini adalah untuk menguji pengaruh good corporate governance (GCG) terhadap kinerja keuangan melalui corporate social responsibility (CSR) pada perusahaan perbankan di BEI. Hasil penelitian ini diharapkan memberikan manfaat sebagai berikut: (1) Memberikan informasi tambahan yang bermanfaat bagi investor, calon investor, perusahaan perbankan dan perusahaanperusahaan lainnya mengenai pengaruh penerapan GCG dan CSR terhadap kinerja keuangan perusahaan. (2) Bagi peneliti selanjutnya, sebagai bahan kajian kinerja keuangan perusahaan dan faktor-faktor yang mempengaruhinya (3) Bagi pemerintah dan Bursa Efek Indonesia, selaku regulator diharapkan dapat dijadikan sebagai gambaran dari efektivitas penerapan GCG dan CSR bagi dunia perbankan, sehingga dapat dibahas lebih lanjut perkembangan regulasi GCG dan CSR.

\section{TINJAUAN TEORITIS DAN HIPOTESIS}

Good Governance (GG) sering diartikan sebagai "tata pengelolaan yang baik" lebih dahulu dikenal dalam praktek manajemen modern (Emye, 2007 dalam Ariyani \& Gunawan, 2014). Pelaksanaan prinsip-prinsip dasar good corporate governance (GCG) harus mempertimbangkan karakter setiap perusahaan Copyright $@ 2017$ AKRUAL: Jurnal Akuntansi 
seperti besarnya modal, pengaruh dari kegiatannya terhadap masyarakat dan lain sebagainya (Arafat, 2008 dalam Ariyani \& Gunawan, 2014). Di Indonesia, pemerintah melalui Keputusan Menteri Koordinator Ekonomi, Keuangan dan Industri No. Kep/31/M.EKUIN/08/1999, telah membentuk suatu badan yang diberi nama Komite Nasional Kebijakan Corporate Governance (KNKCG). Komite Nasional ini bertugas untuk merumuskan dan merekomendasikan kebijakan nasional mengenai pengelolaan perusahaan. Hal yang perlu mendapatkan perhatian adalah penyelarasan dari prinsip-prinsip yang dituangkan dalam pedoman-pedoman GCG di atas dengan kebijakan manajemen (management policy) dan prosedur operasional standar (standard operating procedures) lain (Susilo dan Simarmata, 2007 dalam Ariyani \& Gunawan, 2014).

\section{Pedoman Good Corporate Governance} Perbankan Indonesia (2004) yang dikeluarkan Komite Nasional Kebijakan Corporate Governance (KNKCG) mempaparkan mengenai arti lima prinsip, yakni: "Sebagai lembaga intermediasi dan lembaga kepercayaan, dalam melaksanakan kegiatan usahanya harus menganut prinsip keterbukaan (transparency), memiliki ukuran kinerja dari semua jajaran bank berdasarkan ukuran-ukuran yang konsisten dengan corporate value, sasaran usaha dan strategi bank sebagai pencerminan akuntabilitas bank (accountability), berpegang pada prudential banking practices dan menjamin dilaksanakannya ketentuan yang berlaku sebagai wujud tanggung jawab bank (responsibility), objektif dan bebas dari tekanan pihak manapun dalam pengambilan keputusan (independency), serta senantiasa memperhatikan kepentingan seluruh stakeholders berdasarkan azas kesetaraan dan kewajaran (fainess)". Secara rinci prinsip-prinsip dasar GCG yang disusun oleh OECD terdiri dari 5 aspek yaitu:

1. Transparancy yaitu keterbukaan informasi, baik dalam proses pengambilan keputusan maupun dalam mengungkapkan informasi material dan relevan mengenai perusahaan.

2. Accountability, adalah kejelasan fungsi, struktur, sistem dan pertanggungjawaban organ perusahaan, sehingga pengelolaan perusahaan terlaksana secara efektif. Dengan kata lain prinsip ini menegaskan bagaimana bentuk pertanggungjawaban manajemen kepada perusahaan dan para pemegang saham.

3. Responsibility, pertanggungjawaban perusahaan adalah kesesuaian (kepatuhan) di dalam pengelolaan perusahaan terhadap prinsip korporasi yang sehat serta peraturan perundangan yang berlaku.

4. Independensi, atau kemandirian adalah suatu keadaan dimana prinsip ini menekankan bahwa pengelolaan perusahaan harus profesional tanpa benturan kepentingan dan pengaruh atau tekanan dari pihak manapun, sehingga dapat menghasilkan keputusan yang obyektif. 
AKRUAL: Jurnal Akuntansi, volume 9, nomor 1, Oktober 2017, (41-53)

5. Fairness (kesetaraan dan kewajaran) yaitu perlakuan adil dan setara di dalam memenuhi hak-hak stakeholder yang timbul berdasarkan perjanjian dan peraturan perundang-undangan yang berlaku.

Krugman (1998) menyebutkan bahwa krisis ekonomi di Asia termasuk Indonesia tidak lebih karena praktik buruk perbankan. Sebagian besar perbankan Indonesia mengalami gangguan mendadak ketika krisis ekonomi tiba. Bank merupakan salah satu penggerak pertumbuhan ekonomi melalui pembiayaan yang diberikan. Oleh karena itu, dengan adanya pengelolaan perbankan yang baik melalui aplikasi GCG, maka hal ini akan meningkatkan efisiensi perbankan dan selanjutnya pertumbuhan ekonomi, mengingat perbankan mempunyai sumbangan besar dalam perekonomian. Jika perbankan efisien, maka hal ini akan membawa dampak positif bagi peningkatan keuntungan bank, besaran dana intermediasi bank, membaiknya kualitas pelayanan kepada nasabah, mendorong kemanan operasional, kesehatan perbankan serta yang paling penting keuntungan kepada shareholder dan stakeholder. Bank Indonesia mengeluarkan peraturan PBI 8/4/2006 untuk pelaksanaan GCG bagi bank umum guna meningkatkan compliance terhadap peraturan perundang-undangan yang berlaku dan nilai-nilai etika yang berlaku umum pada perusahaan perbankan.

Natalylova (2013) menggambarakan 4 dimensi GCG yaitu: kepemilikan publik, kepemilikan institusional, ukuran dewan 45 komisaris dan komite audit. Secara rinci, penjelasannya adalah sebagai berikut:

1. Kepemilikan publik

Rasio kepemilikan publik digambarkan dengan proporsi saham perusahaan yang dimiliki publik. Skala ini diukur dengan membandingkan jumlah saham yang dimiliki publik dengan jumlah saham yang beredar. Prosentase kepemilikan publik = (jumlah saham publik / jumlah saham beredar) x $100 \%$

2. Kepemilikan institusional

Kepemilikan institusional menunjukkan prosentase saham yang dimiliki oleh blockholder yaitu kepemilikan individual atas nama perorangan di atas 5\%, tetapi tidak termasuk ke dalam golongan kepemilikan insider. Kepemilikan oleh blockholder dimasukkan ke dalam kepemilikan institusi. Variabel ini diukur dari jumlah prosentase saham yang dimiliki institusi pada akhir tahun. Variabel ini diperoleh dari laporan keuangan pada bagian shareholder. Prosentase kepemilikan institusional $=$ (jumlah saham institusi + jumlah saham block holder) / jumlah saham beredar.

3. Ukuran dewan komisaris

Ukuran dewan komisaris adalah banyaknya jumlah anggota dewan komisaris dalam suatu perusahaan (Wakidi \& Siregar, 2011). Perusahaan yang memiliki dewan komisaris akan mengungkapkan lebih dalam laporan tahunan dan bertanggung jawab kepada pemegang saham serta masyarakat. Ukuran

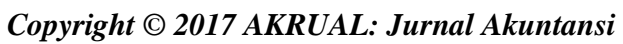




\section{Djamilah, Surenggono, Corporate Social Responsibility Sebagai Variabel Pemediasi...}

dewan komisaris $=$ jumlah anggota dewan komisaris

4. Komite audit

Pengertian dari komite audit adalah komite yang dibentuk oleh dan bertanggung jawab kepada Dewan Komisaris dalam membantu melaksanakan tugas dan fungsi Dewan Komisaris (Peraturan Bapepam-LK Nomor IX.I.05). Komite audit adalah komite yang terdiri dari individu-individu yang mandiri dan tidak terlibat dengan tugas sehari-hari dari manajemen yang mengelola perusahaan dan yang memiliki pengalaman untuk melaksanakan fungsi pengawasan secara efektif. Pedoman Good Corporate Governance tidak mengatur banyaknya anggota Komite Audit dalam suatu perusahaan namun harus disesuaikan dengan kompleksitas Perusahaan dengan tetap memperhatikan efektifitas dalam pengambilan keputusan. Akan tetapi kemudian disebutkan dalam Peraturan Bapepam-LK No IX.I.05 bahwa Komite Audit paling kurang terdiri dari 3 (tiga) orang anggota yang berasal dari Komisaris Independen dan Pihak Luar Emiten atau Perusahaan Publik. Komite audit, diukur dengan anggota komite audit yang dimiliki suatu perusahaan (Siallagan dan Machfoedz, 2006 dalam Wardoyo dan Veronica, 2013). Rumusan untuk menentukan ukuran komite audit adalah sebagai berikut: Ukuran Komite Audit $=\Sigma$ Komite Audit.
Corporate social responsibility (CSR) adalah kepedulian perusahaan yang tidak hanya mencari laba (profit), tetapi juga membangun manusia (people) dan lingkungan (planet) secara berkelanjutan berdasarkan prosedur yang ditentukan. Dengan melaksanakan CSR, image perusahaan akan semakin baik, sehingga loyalitas konsumen semakin tinggi. Seiring meningkatnya loyalitas konsumen dalam waktu yang lama, maka penjualan perusahaan akan semakin membaik, dan pada akhirnya dengan pelaksanaan CSR, diharapkan tingkat profitabilitas perusahaan juga akan meningkat.

Pengungkapan tanggung jawab sosial merupakan hal penting karena saat ini masyarakat sudah semakin peduli terhadap produk yang ramah lingkungan dan juga akibat positif bagi perusahaan terutama bagi kinerja keuangannya. Hal tersebut menjadi indikasi yang penting bagi investor karena dapat digunakan untuk melihat apakah mereka akan mempertahankan investasi di perusahaan tersebut atau mencari alternatif lain (Ariyani \& Gunawan, 2014). Selain itu, pengukuran kinerja perusahaan juga dilakukan untuk memperlihatkan kepada penanam modal maupun pelanggan atau masyarakat secara umum bahwa perusahaan memiliki kreditibilitas yang baik (Munawir, 1995 dalam Ariyani \& Gunawan, 2014).

Menurut Febriyani dan Zulfadin (2003) dalam Ariyani \& Gunawan (2014), kinerja perusahaan merupakan hal penting yang harus dicapai oleh setiap perusahaan dimana pun, karena kinerja merupakan cerminan dari 
AKRUAL: Jurnal Akuntansi, volume 9, nomor 1, Oktober 2017, (41-53)

kemampuan perusahaan dalam mengelola dan mengalokasikan sumber dayanya. Kinerja perusahaan adalah kemampuan perusahaan dalam menjelaskan operasionalnya (Payatma, 2001 dalam Ariyani \& Gunawan, 2014). Kinerja perusahaan juga diartikan sebagai penentuan ukuran-ukuran tertentu yang dapat mengukur keberhasilan suatu perusahaan dalam menghasilkan laba. Dalam mengukur kinerja perusahaan perlu dikaitkan antara perusahaan dengan pusat pertanggungjawaban (Ermayanti, 2009 dalam Ariyani \& Gunawan, 2014). Peningkatan kinerja perusahaan melalui capaian program CSR mengindikasikan etika bisnis yang dijalankan perusahaan, akomodasi pada sumber daya baik bahan baku maupun tenaga kerja, dan juga kredibilitas perusahaan yang semakin meningkat. Indikator suatu perusahaan memiliki kinerja yang baik adalah dengan menggunakan Rasio Profitabilitas, seperti ROA dan ROE.

Beberapa penelitian terdahulu terkait pengaruh GCG dan CSR pada kinerja keuangan perusahaan dan perbedannya dengan penelitian sekarang (Djamilah \& Surenggono, 2016) dapat dilihat di tabel 1.

Tabel 1. Penelitian Terdahulu

\begin{tabular}{|c|c|c|c|c|c|}
\hline $\begin{array}{l}\text { Kete- } \\
\text { rangan }\end{array}$ & $\begin{array}{l}\text { Novrianti, et al. } \\
\text { (2012) }\end{array}$ & $\begin{array}{c}\text { Agustina, et al. } \\
(2015)\end{array}$ & $\begin{array}{c}\text { Fitriani \& Hapsari } \\
\text { (2014) }\end{array}$ & $\begin{array}{c}\text { Ariyani \& } \\
\text { Gunawan } \\
(2014)\end{array}$ & $\begin{array}{c}\text { Djamilah \& } \\
\text { Surenggono } \\
(2016)\end{array}$ \\
\hline $\begin{array}{l}\text { Variabel } \\
\text { bebas }(\mathrm{X})\end{array}$ & $\begin{array}{l}\text { Good corporate } \\
\text { governance (GCG) } \\
\text { dan corporate social } \\
\text { responsibility (CSR) }\end{array}$ & $\begin{array}{l}\text { Intelectual capital, } \\
\text { CSR dan GCG }\end{array}$ & $\begin{array}{l}\text { Good corporate } \\
\text { governance } \\
\text { (GCG) dan } \\
\text { corporate social } \\
\text { responsibility } \\
\text { (CSR) }\end{array}$ & $\begin{array}{l}\text { Good } \\
\text { corporate } \\
\text { governance } \\
\text { (GCG) dan } \\
\text { (CSR) }\end{array}$ & $\begin{array}{l}\text { Good } \\
\text { corporate } \\
\text { governance } \\
\text { (GCG) }\end{array}$ \\
\hline $\begin{array}{l}\text { Variabel } \\
\text { mediasi }\end{array}$ & $\begin{array}{l}\text { Kinerja perusahaan } \\
\text { berupa ROE }\end{array}$ & $\begin{array}{l}\text { Kinerja keuangan } \\
\text { perusahaan berupa } \\
\text { ROE }\end{array}$ & $\begin{array}{l}\text { Kinerja keuangan } \\
\text { perusahaan } \\
\text { berupa ROA }\end{array}$ & $\begin{array}{l}\text { Kinerja } \\
\text { perusahaan } \\
\text { perbankan }\end{array}$ & CSR \\
\hline $\begin{array}{l}\text { Variabel } \\
\text { terikat (Y) }\end{array}$ & & & & $\begin{array}{l}\text { berupa ROA } \\
\text { dan ROE }\end{array}$ & $\begin{array}{l}\text { Kinerja } \\
\text { perusahaan } \\
\text { perbankan } \\
\text { berupa ROA } \\
\text { dan ROE }\end{array}$ \\
\hline $\begin{array}{l}\text { Obyek/ } \\
\text { Sampel } \\
\text { penelitian }\end{array}$ & $\begin{array}{l}11 \text { perusahaan } \\
\text { manufaktur yang } \\
\text { terdaftar di BEI tahun } \\
2009-2011\end{array}$ & $\begin{array}{l}15 \text { perusahaan } \\
\text { BUMN Non } \\
\text { Keuangan yang } \\
\text { terdaftar di Bursa } \\
\text { Efek Indonesia } \\
\text { pada tahun 2011- } \\
2013\end{array}$ & $\begin{array}{l}\text { Perbankan Milik } \\
\text { Pemerintah dan } \\
\text { Swasta yang } \\
\text { Terdaftar di BEI } \\
\text { tahun 2011- } 2013\end{array}$ & $\begin{array}{l}\text { Perusahaan- } \\
\text { perusahaan } \\
\text { perbankan } \\
\text { tahun } 2005 \text { - } \\
2010\end{array}$ & $\begin{array}{l}\text { Perusahaan- } \\
\text { perusahaan } \\
\text { perbankan } \\
\text { tahun } 2010- \\
2014\end{array}$ \\
\hline $\begin{array}{l}\text { Hasil } \\
\text { Penelitian }\end{array}$ & $\begin{array}{l}\text { CSR tidak } \\
\text { berpengaruh pada } \\
\text { ROE dan hanya } \\
\text { komisaris independen }\end{array}$ & $\begin{array}{l}\text { Intelectual Capital, } \\
\text { Corporate Social } \\
\text { Responsibility dan } \\
\text { Good Corporate }\end{array}$ & $\begin{array}{l}\text { 1) GCG dan CSR } \\
\text { secara simultan } \\
\text { berpengaruh } \\
\text { signifikan }\end{array}$ & $\begin{array}{l}G C G \text { dan } C S R \\
\text { berpengaruh } \\
\text { signifikan } \\
\text { pada ROA dan }\end{array}$ & - \\
\hline
\end{tabular}


Djamilah, Surenggono, Corporate Social Responsibility Sebagai Variabel Pemediasi...

\begin{tabular}{llll}
\hline dari GCG yang & Governance & terhadap (ROA) & ROE. \\
berpengaruh pada & berpengaruh & 2) Hanya ukuran \\
kinerja perusahaan & terhadap kinerja & Dewan Direksi \\
berupa ROE. & keuangan (ROA). & berpengaruh \\
& & $\begin{array}{l}\text { positif signifikan } \\
\text { terhadap ROA. }\end{array}$ \\
\hline
\end{tabular}

Sumber: data sekunder diolah

Terdapat 4 komponen GCG, yaitu transparancy, accountability, responsibility, dan fairness. Keempat komponen tersebut penting karena penerapan prinsip good corporate governance secara konsisten terbukti dapat meningkatkan kualitas laporan keuangan dan juga mampu mengurangi aktivitas menyimpang seperti rekayasa isi laporan keuangan yang tidak menggambarkan nilai yang sebenarnya (Kaihatu, 2006). Selain itu, prinsip responsibility dalam penerapan GCG juga dapat mendorong pelaksanaan tanggung jawab sosial perusahaan terhadap masyarakat dan lingkungan sekitar perusahaan.

\section{Untuk melaksanakan CSR berarti} perusahaan akan mengeluarkan sejumlah biaya. Biaya pada akhirnya akan menjadi beban yang mengurangi pendapatan, sehingga tingkat profit perusahaan akan turun. Akan tetapi dengan melaksanakan CSR, image perusahaan akan semakin baik sehingga loyalitas konsumen semakin tinggi. Seiring meningkatnya loyalitas konsumen dalam waktu yang lama, maka penjualan perusahaan akan semakin membaik, dan pada akhirnya dengan pelaksanaan CSR, diharapkan tingkat profitabilitas perusahaan juga meningkat (Satyo, 2005 dalam Fitriani \& Hapsari, 2014).

Berdasarkan penjelasan di atas, maka hipotesis dalam penelitian ini adalah:
H1: Good corporate governance (GCG) yang berupa kepemilikan publik, kepemilikan institusional, dan ukuran dewan komisaris berpengaruh terhadap corporate social responsibility (CSR).

H2: Corporate social responsibility (CSR) berpengaruh terhadap kinerja keuangan yang berupa ROA (return on asset) dan ROE (return on equity) pada perusahaan perbankan di BEI.

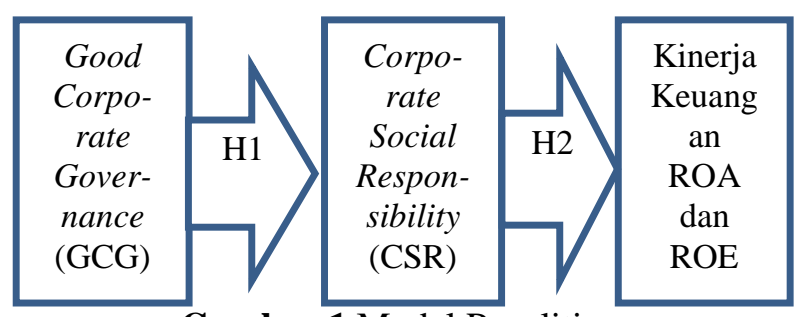

Gambar 1.Model Penelitian

\section{METODA PENELITIAN}

Populasi dalam penelitian ini adalah semua perusahaan perbankan yang tercatat (Go Public) di Bursa Efek Indonesia (BEI) seperti yang tercantum dalam Indonesian Capital Market Directory (ICMD) periode 2010-2014. Teknik pemilihan sampel menggunakan purposive sampling berdasarkan pada kriteria: perusahaan terdaftar di BEI periode 2010-2014, menerbitkan laporan tahunan dan laporan keuangan periode 2010 sampai 2014 dan tidak mengalami kerugian.

Variabel bebas dalam penelitian ini adalah good corporate governance (GCG) yang 
AKRUAL: Jurnal Akuntansi, volume 9, nomor 1, Oktober 2017, (41-53)

berupa kepemilikan publik, kepemilikan institusional dan ukuran dewan komisaris. Sedangkan variabel mediasi adalah corporate social responsibility (CSR). Corporate social responsibility (CSR) adalah suatu konsep akuntansi yang menekankan tanggung jawab perusahaan terhadap lingkungan dan masyarakat. CSR mempunyai 6 (enam) indikator, yang keseluruhannya memuat 78 item. Indikatorindikator tersebut antara lain: a). Indikator kinerja ekonomi b). Indikator kinerja lingkungan c). Indikator praktik tenaga kerja dan pekerjaan yang layak d). Indikator hak asasi manusia e). Indikator masyarakat/sosial f). Indikator tanggung jawab produk. Penilaian ini diungkapkan menurut Global Reporting Initiative (GRI) dengan menyusun daftar (check list) pengungkapan CSR yang digunakan oleh Sembiring (2005) dan menentukan indeks pengungkapan tanggung jawab sosial dengan menggunakan skor 1 untuk yang mengungkapkan dan 0 jika tidak mengungkapkan.

$$
\mathrm{CSR} \mathrm{ij}=\sum \mathrm{Xij} / \mathrm{Nj}
$$

Keterangan:

CSRij : Indeks Corporate Social Responsibility (ICSR)

Xij : Dummy Variabel $\mathrm{Nj}$ : 78 item CSR

Variabel terikat dalam penelitian ini adalah kinerja keuangan. Kinerja keuangan adalah berupa rentabilitas bisnis perbankan yang merupakan kesanggupan bisnis perbankan untuk memperoleh laba berdasarkan investasi yang dilakukannya (Sastradipoera, 2004). Kinerja keuangan perusahaan perbankan dalam penelitian ini adalah berupa ROA dan ROE. 49
Return On Asset (ROA) merupakan rasio untuk mengukur kemampuan manajemen dalam menghasilkan pendapatan dari pengelolaan aset (Kasmir, 2003). Return on Equity (ROE) merupakan rasio untuk mengukur kemampuan manajemen bank dalam mengelola modal yang ada untuk mendapatkan laba bersih (Kasmir, 2003).

Teknik analisis dalam penelitian ini menggunakan SEM (Structural Equation Modelling). SEM adalah sekumpulan teknik statistik yang memungkinkan pengujian sebuah rangkaian hubungan yang relatif rumit, secara simultan. Model penelitian diukur kesesuaiannya dengan melihat goodness of fit sebuah model. Penggunaan beberapa indeks kesesuaian memungkinkan peneliti mendapatkan suatu penerimaan mengenai model yang diusulkan (Hair et al., 2006).

\section{ANALISIS DATA DAN PEMBAHASAN}

\section{Analisis}

Dari 31 bank yang terdaftar di BEI tahun 20102014, ada 29 bank yang memenuhi syarat untuk dijadikan sampel. Jumlah amatan sebanyak 145 amatan (29 bank X 5 tahun). Statistik deskriptif dari penelitian ini adalah sebagai berikut:

Tabel 2. Statistik Deskriptif

\begin{tabular}{lr}
\hline \multicolumn{1}{c}{ Variabel } & \multicolumn{1}{c}{ Rerata } \\
\hline ROA (\%) & 1,5479 \\
ROE (\%) & 13,1417 \\
JUMLAH KOMISARIS & 5,3103 \\
KEPEMILIKAN PUBLIK (\%) & 25,0231 \\
KEPEMILIKAN INSTITUSIONAL (\%) & 74,2890 \\
CSR (\%) & 65,7734 \\
\hline
\end{tabular}

Sumber: Data sekunder diolah 
Djamilah, Surenggono, Corporate Social Responsibility Sebagai Variabel Pemediasi...

Tabel 3. Nilai Kesesuaian Model Empiris

\begin{tabular}{lccc}
\hline \multicolumn{1}{c}{$\begin{array}{c}\text { Goodness of Fit } \\
\text { Index }\end{array}$} & $\begin{array}{c}\text { Cut off } \\
\text { value }\end{array}$ & $\begin{array}{c}\text { Hasil } \\
\text { Riset }\end{array}$ & Keterangan \\
\hline $\begin{array}{l}\rho \text { value } \mathrm{X}^{2} \text {-Chi } \\
\text { square }\end{array}$ & $\geq 0,05$ & 0,000 & Jelek \\
RMSEA & $\leq 0,08$ & 0,316 & Jelek \\
$\begin{array}{l}\text { Goodness of Fit } \\
\text { Index }\end{array}$ & $\geq 0,90$ & 0,819 & Sedang \\
$\begin{array}{l}\text { Comparative Fit } \\
\text { Index }\end{array}$ & $\geq 0,90$ & 0,846 & Sedang \\
$\begin{array}{l}\text { Tucker Lewis } \\
\text { Index }\end{array}$ & $\geq 0,90$ & 0,670 & Sedang \\
NFI & $\geq 0,900$ & 0,839 & Sedang \\
CMIN/DF & $\leq 5,00$ & 7,000 & Jelek \\
\hline
\end{tabular}

Sumber: data sekunder diolah

Tabel 4. Hasil Uji Hipotesis

\begin{tabular}{lccc}
\hline \multicolumn{1}{c}{ Hubungan } & Estimate & C.R. & P \\
\hline Komisaris $\rightarrow$ CSR & 0,874 & 2,715 & 0,007 \\
Kepemilikan Publik & 0,744 & 2,977 & 0,003 \\
$\rightarrow$ CSR & & & \\
Kepemilikan & 0,901 & 3,529 & 0,001 \\
Institusional $\rightarrow$ CSR & & & \\
CSR $\rightarrow$ ROA & 0,023 & 2,419 & 0,016 \\
CSR $\rightarrow$ ROE & 0,249 & 2,990 & 0,003 \\
\hline
\end{tabular}

Sumber: data sekunder diolah

Penelitian ini bertujuan untuk menguji pengaruh good corporate governance (GCG) terhadap kinerja keuangan melalui corporate social responsibility (CSR) pada perusahaan perbankan di BEI tahun 2010 - 2014. Hasil analisis dengan menggunakan SEM program Amos dapat dilihat pada tabel 3 dan 4 .

Hasil goodness of fit index menunjukkan bahwa dari 7 goodness of fit index, ada 4 yang mempunyai nilai kesesuaian yang cukup layak. Oleh karena itu, dilakukan analisis berikutnya yaitu pengujian hipotesis.

Hasil SEM dengan menggunakan program Amos, menunjukkan bahwa variabel GCG yang terdiri dari kepemilikan publik, kepemilikan institusional dan ukuran dewan komisaris berpengaruh positif dan signifikan pada CSR. Hal itu berarti, jika GCG tinggi, maka CSR juga tinggi. Sebaliknya jika GCG rendah, maka CSR juga rendah. Hasil penelitian juga menunjukkan bahwa variabel mediasi CSR berpengaruh positif dan signifikan terhadap ROA dan ROE. Jika CSR tinggi, maka ROA dan ROE juga tinggi. Sebaliknya, jika CSR rendah, maka ROA dan ROE juga rendah. Dalam penelitian ini, CSR berfungsi sebagai variabel pemediasi, pengaruh GCG terhadap ROA dan ROE. Hasil penelitian ini mendukung penelitian Agustina, et al. (2015), Fitriani dan Hapsari (2014) dan Ariyani dan Gunawan (2014), bahwa GCG dan CSR berpengaruh pada kinerja keuangan perusahaan (ROA dan ROE).

\section{PEMBAHASAN}

Tujuan perusahaan dalam penerapan GCG adalah untuk membangun citra perusahaan dan memenuhi tanggung jawab kepada pemegang saham, masyarakat dan kesejahteraan karyawan. Prinsip responsibility dalam penerapan GCG dapat mendorong pelaksanaan tanggung jawab sosial perusahaan (CSR) terhadap masyarakat dan lingkungan sekitar perusahaan.

GCG berupa kepemilikan publik yaitu proporsi saham perusahaan yang dimiliki publik, dan kepemilikan institusional yang berarti pemegang saham berbentuk entitas seperti perbankan, asuransi, dana pensiun, reksadana dan institusional lain. Investor institusional umumnya merupakan pemegang saham yang cukup besar karena memiliki pendanaan yang besar. Tingkat kepemilikan publik dan institusional yang tinggi menimbulkan usaha pengawasan tinggi untuk menghalangi perilaku manajer yang oportunistik dan dapat mengurangi 
AKRUAL: Jurnal Akuntansi, volume 9, nomor 1, Oktober 2017, (41-53)

masalah keagenan. Perusahaan yang memiliki dewan komisaris tinggi akan mengungkapkan lebih banyak dalam laporan tahunan dan bertanggung jawab kepada pemegang saham dan masyarakat. GCG berupa kepemilikan publik, kepemilikan institusional dan jumlah komisaris yang tinggi mendorong munculnya tuntutan untuk peduli dengan lingkungan sekitar perusahaan. Publik atau masyarakat sebagai pemegang saham perusahaan tidak hanya menginginkan laba perusahaan yang tinggi, tapi juga menginginkan perusahaan untuk berperan dalam tanggun jawab sosial. Dengan demikian, good corporate governance (GCG) yang tinggi akan mendorong corporate social responsibility (CSR) yang tinggi.

Dengan melaksanakan CSR, citra perusahaan akan semakin baik, sehingga kepuasan konsumen semakin tinggi dan demikian juga dengan loyalitas konsumennya. Adanya kepedulian perusahaan terhadap masyarakt yang tinggi, membuat masyarakat percaya dan bersedia menitipkan uangnya ke bank ataupun mengambil kredit di bank tersebut. Loyalitas konsumen (nasabah) yang tinggi berdampak pada pendapatan atau profitabilitas yang tinggi. CSR yang tinggi bukanlah beban, tetapi merupakan investasi sosial yang menjamin masyarakat tidak melakukan gangguan operasional pada bank, misalnya tuntutan hukum dari masyarakat. Dengan demikian pelaksanaan CSR, dapat meningkatkan profitabilitas.

\section{KESIMPULAN}

\section{Kesimpulan}

Hasil penelitian ini menunjukkan bahwa CSR (corporate social responsibility) berfungsi sebagai variabel pemediasi, pengaruh GCG (good corporate governance) yang berupa kepemilikan publik, kepemilikan institusional dan ukuran dewan komisaris terhadap ROA (return on asset) dan ROE (return on equity) dari perusahaan perbankan pada periode 2010 sampai 2014. GCG berpengaruh positif dan signifikan terhadap CSR dan CSR berpengaruh positif dan signifikan pada ROA dan ROE. Hal itu berarti, jika GCG tinggi, maka CSR juga tinggi dan jika CSR tinggi, maka ROA dan ROE juga tinggi. Dapat dikatakan bahwa, jika perbankan menginginkan ROA dan ROE tinggi, maka perbankan harus meningkatkan GCG (good corporate governance) dan CSR (corporate social responsibility).

\section{Implikasi}

Hasil penelitian ini menyarankan pada investor untuk berinvestasi pada perusahaan yang mempunyai good corporate governance (GCG) dan corporate social responsibility (CSR) yang tinggi, sehingga return on asset (ROA) dan return on equity (ROE) juga tinggi. Perusahaan dalam hal ini perbankan sebaiknya tidak raguragu dalam mengeluarkan CSR, karena terbukti CSR dapat meningkatkan ROA dan ROE. Perusahaan juga perlu mempublikasan kegiatan CSRnya, sehingga masyarakat luas mengetahuinya dan berujung pada lahirnya kepercayaan masyarakat terhadap perbankan. Sebaiknya dalam pelaksanaan CSR, perbankan melibatkan 
Djamilah, Surenggono, Corporate Social Responsibility Sebagai Variabel Pemediasi...

masyarakat, terutama masyarakat sekitar lokasi perbankan, misalnya pemberian gerobak dorong pada pedagang kaki lima; memberi modal/kredit ringan pada usaha mikro, kecil dan menengah; memperbaiki fasilitas umum di sekitar lokasi bank; berdonasi pada kegiatan masyarakat contoh saat ulang tahun kemerdekaan Indonesia dan saat peringatan hari besar keagaamaan. Pemerintah juga harus berpartisipasi dalam kegiatan CSR perusahaan, bukan hanya dengan mengeluarkan regulasi (undang-undang) CSR, tapi juga menyelenggarakan kegiatan sosialisai pentingnya CSR dilakukan oleh perbankan dan melakukan monitoring kegiatan CSR yang dilakukan perbankan. Selain itu, pemerintah juga dapat berperan sebagai mitra CSR perbankan, misalnya Dinas Sosial di Kabupaten dapat menjadi penyalur dana CSR dari perbankan di kabupaten tersebut.

\section{Keterbatasan}

Penelitian ini menggunakan sampel hanya perusahaan perbankan, oleh karena itu penelitian selanjutnya sebaiknya menggunakan sampel di luar perbankan, misalnya perusahaan manufaktur. Perusahaan manfaktur biasanya memproduksi barang yang kemungkinan ada limbah yang berdampak pada masyarakat, sehingga CSR merupakan hal wajib bagi perusahaan. Penelitian ini menggunakan periode amatan tahun 2010 - 2014, oleh karena itu penelitian selanjutnya sebaiknya menggunakan periode amatan yang terbaru, misalnya tahun 2015 - 2017. Variabel bebas dalam penelitian ini hanya menggunakan variabel GCG yang berpengaruh pada CSR. Oleh karena itu, sebaiknya penelitian yang akan datang menggunakan variabel bebas lainnya, misalnya asset perusahaan, hutang perusahaan dan ekuitas. Penelitian ini juga menggunakan variabel terikat berupa ROA dan ROE, sebaiknya penelitian yang akan datang menggunakan variabel terikat lainnya, seperti nilai perusahaan, pendapatan saham, deviden yield, harga saham dan lain-lain yang bedampak langsung pada investor saham.

\section{DAFTAR PUSTAKA}

Agustina, W., Yuniarta, G. A., Ak, S., \& Sinarwati, N. K. (2015). Pengaruh Intelectual Capital, Corporate Social Responsibility Dan Good Corporate Governance Terhadap Kinerja Keuangan (Studi Kasus Pada Perusahaan Bumn Yang Terdaftar Di Bursa Efek Indonesia Pada Tahun 2011-2013). Jimat (Jurnal Ilmiah Mahasiswa Akuntansi S1), 3(1).

Ariyani, Ratna Dewi \& Gunawan, Juniati. (2014). Pengaruh pengungkapan good corporate governance dan corporate social responsibility terhadap kinerja perusahaan perbankan, e-journal magister akuntasi trisakti, volume. 1 nomor. 2: 181-198

Amri, Chairul. (2011). Analisis Pengaruh Kinerja Keuangan, Good Corporate Governance dan Corporate Social Responsibility terhadap Nilai Perusahaan. Skripsi. Fakultas Ekonomi. Universitas Gunadarma

Fachrudin, K. A. (2011). Analisis Pengaruh Struktur Modal, Ukuran Perusahaan, dan Agency Cost Terhadap Kinerja Perusahaan. Jurnal akuntansi dan keuangan, 13(1), 37-46. doi.org/10.9744/jak.13.1.37-46

Fitriani, 1. D. \& Hapsari, D. W. 2014. Pengaruh good corporate governance dan corporate social Responsibility terhadap kinerja keuangan perusahaan (studi pada perbankan milik pemerintah dan swasta yang terdaftar di BEI tahun 2011-2013) 
Hair, J. F., Black, W. C., Babin, B. J., Anderson, R. E., \& Tatham, R. L. (1998). Multivariate data analysis (Vol. 5, No. 3, pp. 207-219). Upper Saddle River, NJ: Prentice hall.

Kaihatu, T. S. (2006). Good corporate governance dan penerapannya di indonesia. Jurnal Manajemen dan Kewirausahaan, 8(1), pp-1.

Krugman, P. (1998). Rationales for Rationality. Rationality in Economics: Alternative Perspectives, 111-122. doi:10.1007/97894-011-4862-7 7

Natalylova, K. (2013). Pengaruh Corporate Governance Terhadap Corporate Social Responsibility Dan Kinerja Perusahaan Yang Mendapatkan Indonesia Suistainabilty Reporting Awards. Media Bisnis, 5(3), 162-182.

Novrianti, V., Gusnardi \& Armas, R. (2012). Pengaruh corporate social Responsibility dan good corporate governance terhadap kinerja perusahaan (studi pada perusahaan manufaktur di BEI tahun 2009-2011) diunduh di http://repository.unri.ac.id. /bitsream/ diakses 5 September 2017
Said, R., Hj Zainuddin, Y., \& Haron, H. (2009). The relationship between corporate social responsibility disclosure and corporate governance characteristics in Malaysian public listed companies. Social Responsibility Journal, 5(2), 212-226. doi:10.1108/17471110910964496

Surat Edaran Bank Indonesia Nomor 13/ 24/ DPNP 25 Oktober 2011 Tentang Penilaian Tingkat Kesehatan Bank Umum.

Sutedi, A. (2011). Good Corporate Governance. Jakarta: Sinar Grafika.

Undang-Undang Republik Indonesia Nomor 40 Tahun 2007 Tentang Perseroan Terbatas

Wakidi, R.H., \& Siregar, H. (2011). Pengaruh Sisi Internal dan Eksternal Perusahaan Terhadap Pengungkapan Tanggung Jawab Sosial Pada Perusahaan Manufaktur yang Terdaftar di BEI. Jurnal Ekonom, 14 (4).

Wardiah, M. L. (2013). Dasar-Dasar Perbankan. Bandung. CV Pustaka Setia.

Wardoyo \&Veronica, T. R. 2013. Pengaruh Good Corporate Governace, Corporate Social Responsibility \& Kinerja Keuangan Terhadap Nilai Perusahaan. Jurnal Dinamika Manajemen, 4(2):132-149. 